\title{
The pollution of water resources and interventions to mitigate and control environmental impact
}

\author{
F. Patania, A. Gagliano, F. Nocera \& A. Galesi \\ Department of Industrial and Mechanics Engineering, \\ (DIIM) - Environmental Section, Catania University, Italy
}

\begin{abstract}
The urban sewage coming from residential or commercial compounds are mainly characterized with wastes of human metabolism or activities linked to the use of compounds as cleaning, washing, watering and so on.

Especially in the sewage of metropolitan areas, new categories of pollutants, so called "Emerging Pollutants" (EP), were found. The polluting contents of EP are those that are residual coming from medicines, products used for skin and hair care, antibiotics for human and animal use, endocrine interferents, illegal drugs and so on.

On this ground the paper wants to focalize on the Italian regulations and relating statuary treatments of water at the present time which do not take into consideration this new shape of pollution. After a short sketch of statutory treatments scheduled by regulations, the paper also tries to envisage in which way it might be possible to cope with this new polluting problem by advanced waste water treatments. For reason of room, the "water line" of urban sewage purification will be treated, leaving the "mud line" to another future paper.

Keywords: urban sewage, emerging pollutants, control.
\end{abstract}

\section{Preliminary remarks}

Pollution can be defined by the contents in water of so-called "load parameters" classified in typologies as shown in Table 1. Draining waters coming from household sewage's present values significantly unequal compared 
to natural water as shown for some of them in Table 2. The typologies of pollutants in function of the kind of polluting agents are briefly reported in Table 3.

Table 1: $\quad$ Load parameters.

\begin{tabular}{|l|l|l|}
\hline $\begin{array}{l}\text { A) Autochthonous Load } \\
\text { Parameters }\end{array}$ & $\begin{array}{l}\text { C) Anthropic Load } \\
\text { Parameters }\end{array}$ & $\begin{array}{l}\text { E)Toxic Load } \\
\text { Parameters }\end{array}$ \\
\hline A1) pH & & \\
\hline A2) temperature & C1) BOD5 & E1) Arsenic \\
\hline A3) electrical conductivity & C2) COD & E2) Cadmium \\
\hline A4) total hardness & C3) total phosphorus (as P) & $\begin{array}{l}\text { E3) total chromium and } \\
\text { hexavalent chromium }\end{array}$ \\
\hline A5) sulfate & C4) ammonia nitrogen & E4) Mercury \\
\hline A6) chlorides & C5) nitrous oxide & E5) nickel \\
\hline A7) nitric & $\begin{array}{l}\text { C6) extractable substances in } \\
\text { petroleum ether }\end{array}$ & E6) Lead \\
\hline A8) dissolved oxygen & $\begin{array}{l}\text { (mineral oils, animal fats and } \\
\text { vegetable) }\end{array}$ & E7) copper \\
\hline A9) sodium & C7) anionic & E8) zinc \\
\hline A10) iron & C8) soluble orthophosphates & E9) cyanide \\
\hline A11) Manganese & & E10) sulphides \\
\hline B ) Optical Load Parameters & $\begin{array}{l}\text { D ) Batteric Load } \\
\text { Parameters }\end{array}$ & E11) sulfite \\
\hline B1) turbidity & & E12) total phenols \\
\hline B2) coarse materials & D1) total coliforms & E13) pesticides \\
\hline B3) materiali sedimentabili & D2) fecal coliform & E14) fluorides \\
\hline B4) Total suspended solids & D3) faecal streptococci & E15) free chlorine \\
\hline B5) volatile suspended solids & $\begin{array}{l}\text { D4) sulphite-reducing } \\
\text { clostridia }\end{array}$ & \\
\hline
\end{tabular}

Table 2: $\quad$ Comparison between draining and natural water.

\begin{tabular}{|c|c|c|}
\hline PARAMETERS & $\begin{array}{c}\text { NATURAL } \\
\text { WATER }\end{array}$ & $\begin{array}{c}\text { DOMESTIC } \\
\text { SEWAGE }\end{array}$ \\
\hline $\mathrm{pH}$ & $7,5-8,5$ & $6,8-7,5$ \\
\hline Total suspended solids $(\mathrm{mg} / \mathrm{l})$ & $5-80$ & $200-50000$ \\
\hline $\mathrm{BOD} 5\left(\mathrm{mgO}_{2} / \mathrm{l}\right)$ & $1-15$ & $80-20000$ \\
\hline $\mathrm{COD}\left(\mathrm{mgO}_{2} / \mathrm{l}\right)$ & $5-50$ & $200-100000$ \\
\hline ammonia nitrogen $(\mathrm{mgN} / \mathrm{l})$ & $0-7$ & $10-300$ \\
\hline Nitrous oxide $(\mathrm{mgN} / \mathrm{l})$ & $0-0,3$ & $0-0,5$ \\
\hline nitrate nitrogen $(\mathrm{mgN} / \mathrm{l})$ & $0,5-10$ & $0-1$ \\
\hline total nitrogen $(\mathrm{mgN} / \mathrm{l})$ & $5-10$ & $20-500$ \\
\hline total phosphorus $(\mathrm{mgP} / \mathrm{l})$ & $0-3$ & $1-100$ \\
\hline chloride $(\mathrm{mgCl} / \mathrm{l})$ & $20-100$ & $50-1000$ \\
\hline Total coliforms $(\mathrm{cfu} / \mathrm{ml})$ & $1-200$ & $10^{5}-10^{7}$ \\
\hline total surfactants $(\mathrm{mg} / \mathrm{l})$ & $0-1$ & $5-50$ \\
\hline
\end{tabular}


Table 3: $\quad$ Types of pollutants.

\begin{tabular}{|c|c|}
\hline \multirow{4}{*}{ Conventional pollutants } & Total suspended solids \\
& Solid colloidal \\
& BOD, COD, TOC \\
& Ammonia, nitrates, nitrites, total nitrogen \\
& Phosphorus \\
& Bacteria, cysts, oocysts of protozoa, viruses \\
\hline Non-conventional & Refractory organic substances \\
pollutants & Volatile organic compounds \\
& Surfactants \\
& Metals \\
& Total dissolved solids \\
\hline Emerging pollutants & Prescribed and non-prescription drugs \\
& Care products and hygiene personal \\
& Antibiotics for human and animal \\
& Endocrine disruptors \\
& Illicit drugs \\
\hline
\end{tabular}

\section{Italian regulations}

Current regulations do not take into account so-called "Emerging Pollutants" (EP), shown in Table 3, since the pollution of water is presently ruled by Legislative Decree (LD n.152/2000 that basically is strictly related to the Cadre Directive on Water (CDW) 200/60/CE and the European Decision (ED) n.2455/2011/ CEE too.

The Italian LD specifies the parameters that must be controlled (Annex n.1 to LD) and defines the various standards for BOD, COD, etc. The LD dictates, in addition, the obligation to monitor additional parameters (surfactants, hydrocarbons, etc, etc.) with relation to those concentration limits previously appointed by Ministerial Decree (MD) n.307/2003. Moreover, the LD imposes that the so-called "Apposite Treatment" (AT) must be carried out before delivering waste waters in "Environmental Terminal Delivery" (ETD) (sea, lake, soil, etc, etc.). The term AT is defined by Italian rules as "those treatments of waste water by means of those processes and systems able to guarantee the compliance of terminal Receiving Environmental Bodies (REB) with their quality targets, whether the REB is a surface or underground water body or the ground". The AT must further be able to bring back into the limit of rules the concentrations of polluting contents of water by the so-called method of Equivalent Inhabitants" (EI) that originated the household sewage. The term EI is clearly defined by Italian rules as "the amount of biodegradable loads" (ABL) that need a $\mathrm{BOD}_{5}$ equal to $60 \mathrm{gr} /$ day.

\section{The treatments}

The AT mentioned in Italian regulations needs a scale of processing in subsequent temporal order such as to ensure the "quality standard" of ETD. A logical pattern flow to face the problem of purification could be that reported in 
figure 1 , where $\mathrm{p}^{*}$ are that points of flow where it could be necessary to apply a suitable test analysis to check the presence and concentrations of EP.

The order of AT in Italian Regulations foresees:

- Preliminary treatment which must separate out of sewages the solid matter (detritus, sands, oil, etc, etc).

- Preliminary treatment which must remove Total Suspended Solid (TSS) essentially constituted by organic matter with the target to reduce the BOD5 down to $20 \%$ and TSS down to $50 \%$.

- Secondary treatment which must remove both Biodegradable Organic Matter (BOM) and not settling Colloid Solid (CS) to obtain the end further average reduction respectively of $80 \%$ of BOD5, $75 \%$ of COD and $90 \%$ of TSS.

- Tertiary treatment which must reduce the load of nutrient elements ( $P$ and $\mathrm{N})$ and those substances not much biodegradable also called "bioresistant".

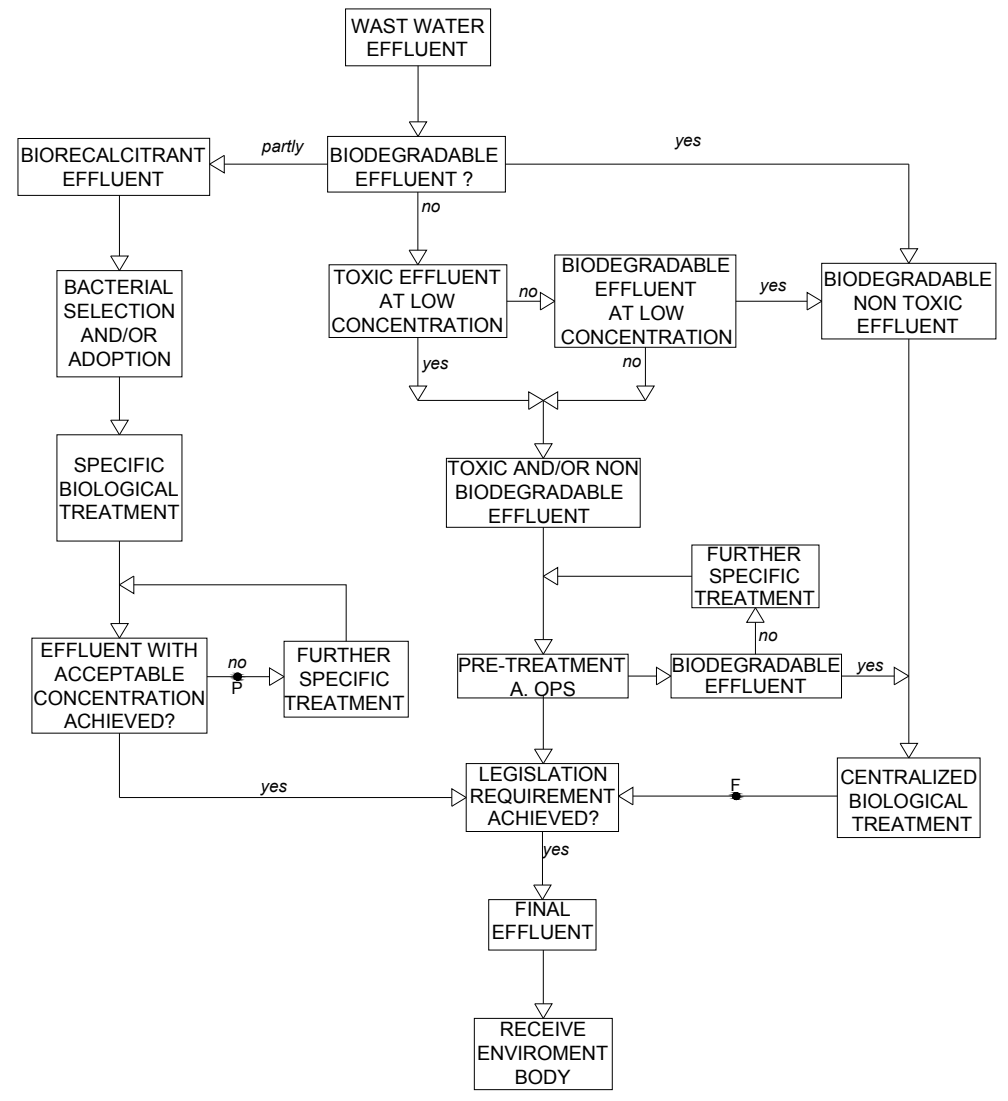

Figure 1: Logical pattern flow. 
The modern technologies makes available a wide range of high efficiency plants and systems able to carry out treatments reports in Table 4 and there is too large a technical bibliography showing the various chemical processes (and their correlated plants) both from physical processes and physical-chemical reactions' points of view [1-3].

Table 4: $\quad$ The main processing present in the various orders of AT.

\begin{tabular}{|c|c|c|c|c|}
\hline $\begin{array}{c}\text { PRE- } \\
\text { TREATMENT }\end{array}$ & PRIMARY & SECONDARY & TERZIARY & $\begin{array}{c}\text { DISINFECTION } \\
\text { TREATMENT }\end{array}$ \\
\hline $\begin{array}{c}\text { Separation } \\
\text { gridding }\end{array}$ & $\begin{array}{c}\text { Primary } \\
\text { sedimentation }\end{array}$ & $\begin{array}{c}\text { Biological } \\
\text { oxidation }\end{array}$ & $\begin{array}{c}\text { Nitrogen } \\
\text { removal }\end{array}$ & Chlorination \\
\hline $\begin{array}{c}\text { De-sand } \\
\text { Blasting and } \\
\text { De-oiling }\end{array}$ & $\begin{array}{c}\text { Clarify } \\
\text { flocking }\end{array}$ & $\begin{array}{c}\text { Anaerobic } \\
\text { digestion }\end{array}$ & $\begin{array}{c}\text { Phosphorus } \\
\text { removal }\end{array}$ & Ozonization \\
\hline $\begin{array}{c}\text { Equalizing and } \\
\text { Homogenizing }\end{array}$ & Flottation & $\begin{array}{c}\text { Secondary } \\
\text { sedimentation }\end{array}$ & filtration & $\begin{array}{c}\text { Ultraviolet rays } \\
\text { treatment }\end{array}$ \\
\hline Pre-airing & & & Absorption & \\
\hline Neutralizing & & & & \\
\hline
\end{tabular}

In this paper, the authors, on the other hand, want to draw attention to the new kind of water pollution called "Emerging Polluting" and their environmental clean up.

\section{Emerging Pollutants (EP)}

Among the emerging pollutants, the main samples are medicines, drugs and products of personal hygiene and beauty care (PPCPs), endocrine interfering (EDC) and total solid dissolved (TSD) too.

Moreover, there are some products too normally utilized in the urban environment such as disinfectants, nitrosodimethyl ammine (NDMA), fuel additives, such as methyl-tert-butyl-ether (MTDE) and fire retardants, such as hexabromocyclodecane (HBCD) and polybrominated diphenyl ethers (PBDE) [4].

A common distinctive feature of EP are to be so small sized that they are below surveying standards established by current Italian regulations as shown in figure 2 .

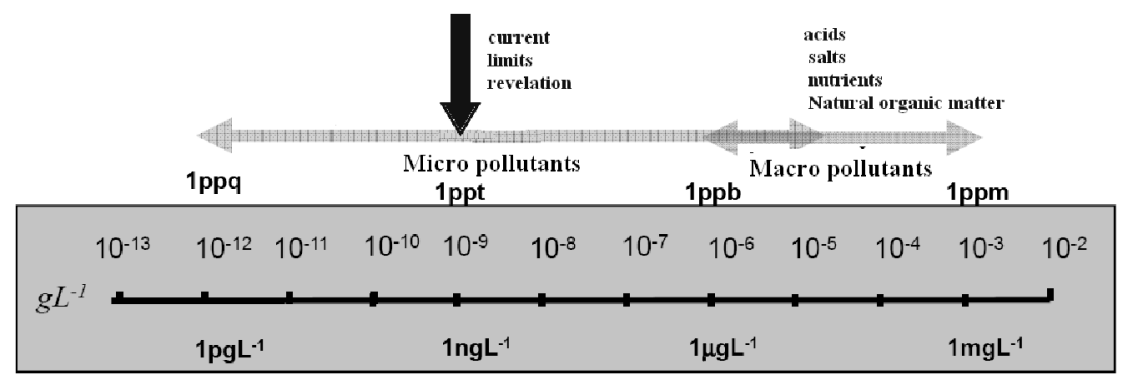

Figure 2: $\quad$ The surveying limits of current Italian rules. 
Figure 3 shows sizes and molecular weight of PPCPs and EDC compared with other substances.

Figure 4 below shows the EP concentrations found in effluents of some purification plants.

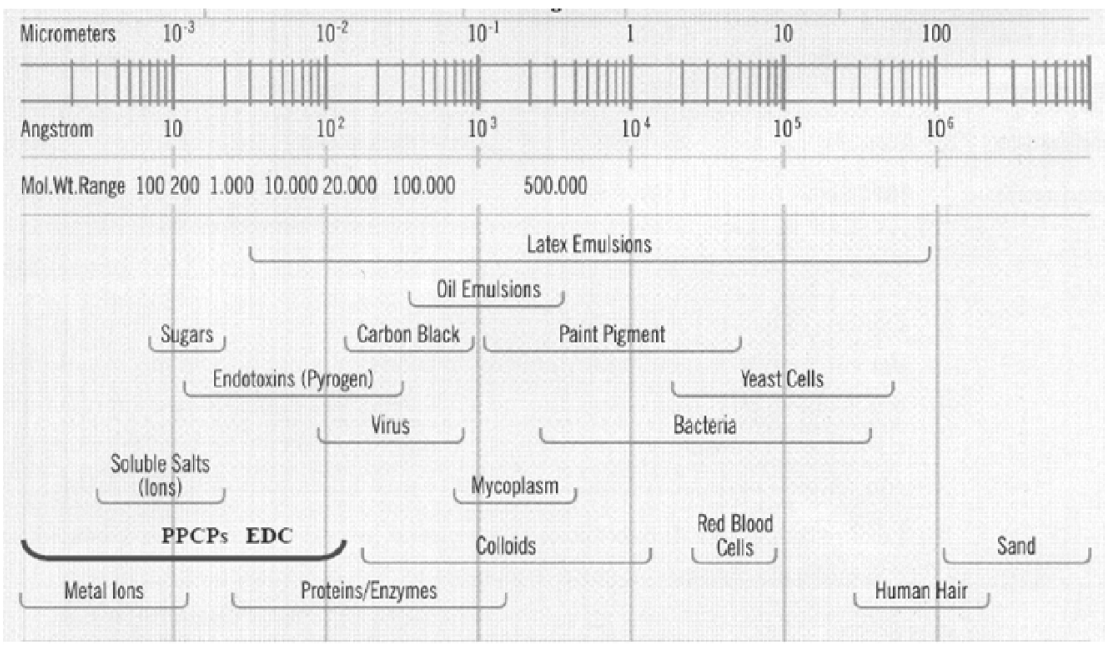

Figure 3: Sizes and molecular weight of PPCPs and EDC compared with other substances.

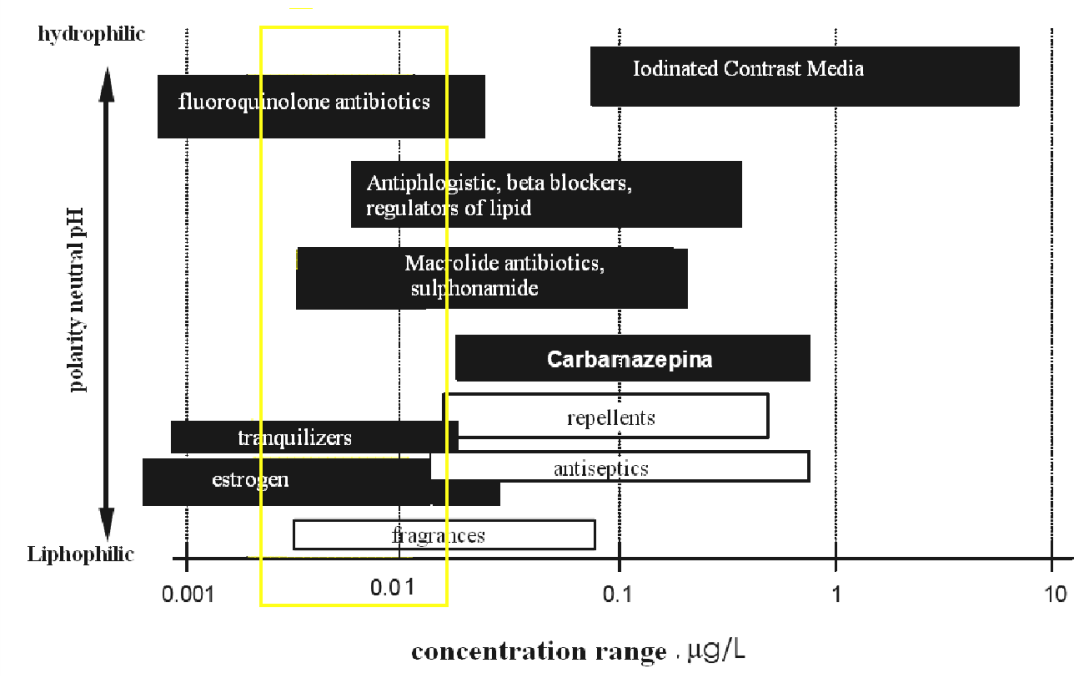

Figure 4: The EP concentrations found into effluents of some purification plants. 
The regulation of draining water coming from purification plants before or after running the time must be completed to take in account of EPr presence into draining water and of their adverse effects on environment and on human health

The suggestions of actions to complete the regulations are:

- To specify what markers must put under investigation into the surface and draining water to classify the presence of EP as pollutants

- To define the methodology of analysis that must be done and to trial the methodologies by pilot plants

- To carry out after the choice of methodology, the tertiary treatments able to achieve the best effectiveness both in technical and economical ways

\section{The treatments in advanced course of study}

The tertiary treatments in advanced course of study to face EP problem as things stand now mainly bring to:

- Micro and ultra filtration

- Photochemical process

- Inverse osmosis and nanofiltration

- Photo-Fenton process

The Photo- Fenton process could be that one with larger future development as it is the likelihood to make use of renewable energy (solar energy) to improve the effectiveness of process both as speed of reaction of process and reduction of power source,

\section{Photo-Fenton process}

The efficient process to face the EP in waste water treatment could seen PhotoFenton (Ph-F) process [4-6] .The Ph-F process improve the efficiency of Fenton reaction(1), also called dark- Fenton

$$
\mathrm{H}_{2} \mathrm{O}_{2}+\mathrm{Fe}^{2+} \rightarrow \mathrm{Fe}^{3+}+\mathrm{HO}^{-}+\mathrm{HO}
$$

It is well known that hydroxyl radical $\left(\mathrm{HO}^{-}\right)$[7-9] is one of the most powerful oxidant universally recognized. The mechanism of oxidation of (1) has been expanded and revised by many Scientists until experiments of Wadley and Wait in 2004 These Scientist demonstrated that hydroxyl radicals produced by Fenton reaction by decomposition of hydrogen peroxide when reacting with ferrous ions if stimulating with sunlight or an artificial sources of wavelengths $(180-400$ $\mathrm{nm}$ ) increases the rate of contaminant degradation mainly stimulating the reduction of $\mathrm{Fe}^{3+}$ to $\mathrm{Fe}^{2+}$. In a very short synthesis equation (1) was turned into equation (2), so called by Person in the 2004 Photo-Fenton reaction

$$
\mathrm{Fe}^{3+}+\mathrm{H}_{2} \mathrm{O} \stackrel{h v}{\rightarrow} \mathrm{Fe}^{2+}+\mathrm{H}^{+}+\mathrm{HO}
$$


In the Photo-Fenton reaction the concentration of hydroxyl radicals becomes higher with the consequence of promoting a faster degradation of the pollutant.

Theoretically, by combination of Fenton and Photo-Fenton reaction, two moles of $\mathrm{OH}^{-}$should be produced per mole of $\mathrm{H}_{2} \mathrm{O}_{2}$ consumed. All scientists agree that hydroxyl radicals formed by complex reaction mechanism oxidize organic species making the start of a radical chain oxidation (3), generating organic radical species which undergo oxidation (4) up to mineralization (5)

$$
\begin{gathered}
\mathrm{HO}+\mathrm{RiH} \rightarrow \mathrm{H}_{2} \mathrm{O}+\mathrm{Ri}^{\circ} \\
\mathrm{Ri}+\mathrm{H}_{2} \mathrm{O}_{2} \rightarrow \mathrm{ROH}+\mathrm{HO} \\
\mathrm{Ri}+\mathrm{O}_{2} \rightarrow \mathrm{RiOO}
\end{gathered}
$$

In the case, for example, of chlorinated compound $\mathrm{Cl}^{-}$it is realized in accordance with (6)

$$
\text { Intermediates }+\mathrm{HO} \rightarrow \mathrm{CO}_{2}+\mathrm{H}_{2} \mathrm{O}+\mathrm{Cl}^{-}
$$

The mechanism pathway of $\mathrm{Ph}-\mathrm{F}$ process according to the classic interpretation is even more complex, but for room reason, we limit ourselves to show reactions (7), (8), and (9) that simplify the main scavenging effect that may occur during the process

$$
\begin{gathered}
\mathrm{HO}+\mathrm{HO} \rightarrow \mathrm{H}_{2} \mathrm{O}_{2} \\
\mathrm{HO}+\mathrm{H}_{2} \mathrm{O}_{2} \rightarrow+\mathrm{HO}_{2}+\mathrm{H}_{2} \mathrm{O} \\
\mathrm{Fe}^{2+}+\mathrm{HO}^{\cdot}+\mathrm{Fe}^{3+}+\mathrm{HO}^{-}
\end{gathered}
$$

At least many authors agree that reaction (10) could describe the real photochemical reduction

$$
\left[\mathrm{Fe}(\mathrm{OH})\left(\mathrm{HO}_{2}\right)\left(\mathrm{H}_{2} \mathrm{O}\right)_{4}\right]^{+*}+\mathrm{H}_{2} \mathrm{O} \quad \leftrightarrow\left[\mathrm{Fe}(\mathrm{OH})\left(\mathrm{H}_{2} \mathrm{O}\right)_{5}\right]^{+}+\mathrm{HO}_{2}
$$

Concerning the photo enhanced process (10) it has also been shown that UV irradiation accelerates the recycling of $\mathrm{Fe}^{2+}$.

The acceleration might be due to photo induced oxidation of the linked of various iron (III) complexes and this kind of process is faster than the reduction of iron(III) to iron (II) described in reaction (2) $[10,11]$.

Considering the successive evolution of solar $\mathrm{Ph}-\mathrm{F}$, it is possible to suppose that it could be an opportune utilization of solar thermal radiation for the $\mathrm{Ph}-\mathrm{F}$ process in consideration too of thermal energy connects with solar energy. As a matter of fact, photons in wavelengths included between 300 and $500 \mathrm{~nm}$ solar radiations can facilitate photochemical conversion of $\mathrm{Fe}^{3+}$ to $\mathrm{Fe}^{2+}$, whereas photons in all remaining wavelengths supply thermal energy that increases the temperature of process that results in an optimal reaction condition. 
Among the many solar reactors tested, the compound Parabolic Collector (CPC) shows the most efficient light collection for low concentrating system as matter of fact that CPC:

- It has no mobile parts

- It is able to collect almost all the direct and diffuse radiation incident in the capitation area

- It is available for photochemical process in reactor

- May be easily up-scaled owing to the simple engineering concepts involved

Figure 5 shows the global irradiance solar spectrum. Figure 6 shows a model of CPC.

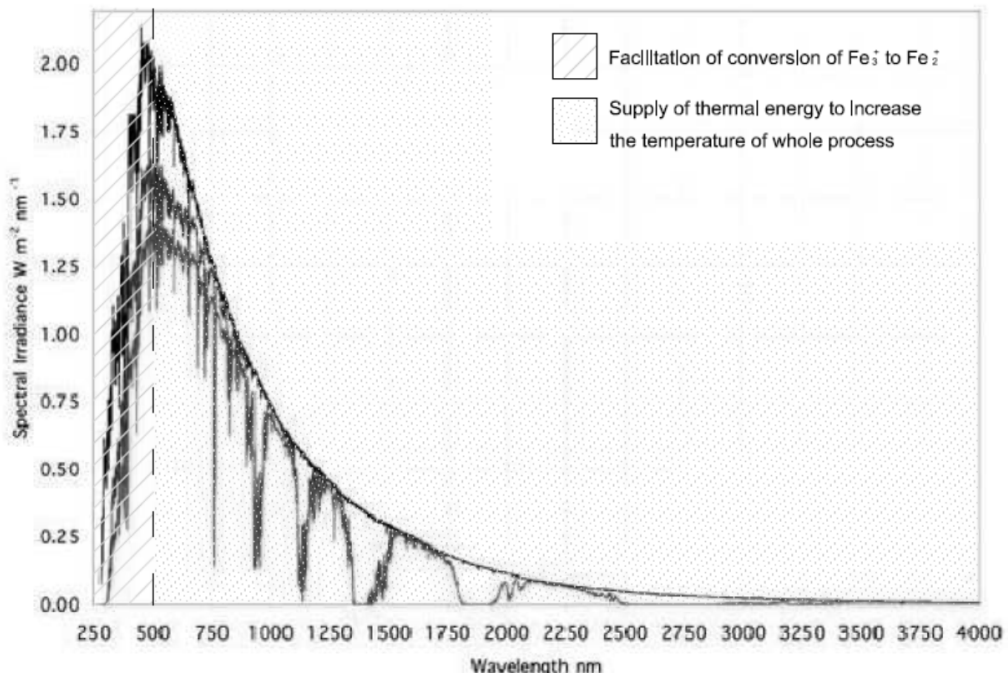

Figure 5: The global irradiance solar spectrum.
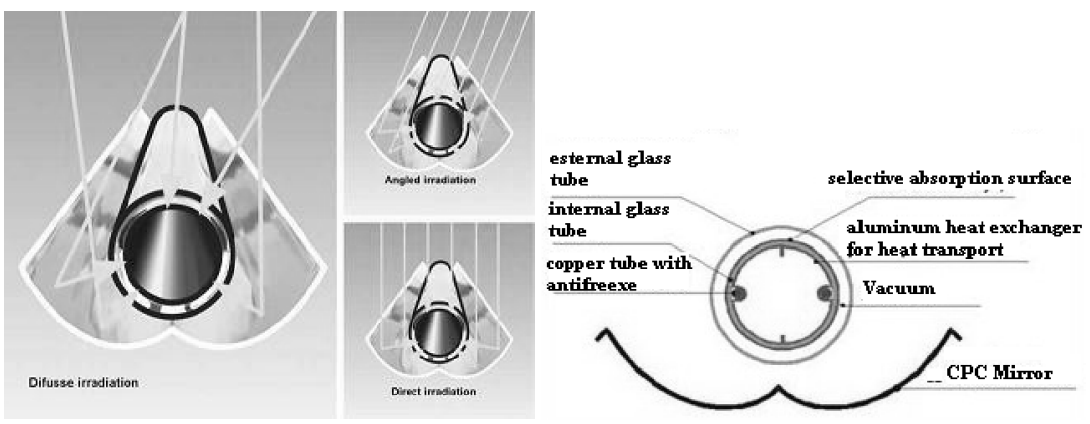

Figure 6: $\quad$ Model of CPC. 


\section{Conclusions}

The presence more and more considerable of concentration of EP into the draining water of purification plants urges us into updating the regulations concerning the pollution of waste water. On this ground the authors believe:

- Upstream of regulation it is necessary to carry out both careful research and classification to determine which kinds of EP and at what concentrations are true concerns for the living and not-living environment.

- In research must be interested the whole Research Organization and the Universities with high specific expertise in fields such as chemistry, pharmacy, sanitary and genetic engineering, environmental control engineering, etc. etc.

- Both the theoretical basic and applied research must give responses to a set of questions as like:

○ In which way is it possible to pitch-out the true sources of this kind of pollution?

- How can people reduce the consumption of PPcPs and EDC?

- What are the new molecules (green pharmacy) that can replace the EP compounds in a way so as to involve a compatible interference with the living and not living environment?

- What could be the tertiary treatments and relating equipments able to remove or reduce the EP concentrations to within compatible limits to human health?

To reach previous goals the research must carry on!!

\section{References}

[1] Charles Gilman, Currier Water, Purification, Biblio Bazaar, 2010

[2] Thomas J., Svoronos, Paris D. N., CRC Handbook of Basic Tables for Chemical Analysis; CRC Press; 1989

[3] Clesceri, Leonore S., Eaton, Andrew D. and Greenberg, Arnold E. (eds); Standard Methods for the Examination of Water and Wastewater (19th edition); American Public Health Association, American Water Works Association and Water Environment Federation; 1995

[4] Townshend, Alan; Encyclopedia of Analytical Science; Academic Press; 1995

[5] Andreozzi R., Apuzzo A.D., Marotta R., A kinetic model for the degradation of benzothiazole by $\mathrm{Fe} 3+$-photo-assisted Fenton process in a completely mixed batch reactor. J. Hazardous Materials B., 80(3): 241-257.

[6] Bossmann, S.H., and others. New evidence against hydroxyl radicals as reactive intermediates in the thermal and photochemically enhanced Fenton reactions. J. Phys. Chem. A., 102(28): 5542-5550. 
[7] Bossmann S.H and others .Oxidative degradation of polyvinyl alcohol by the photochemically enhanced Fenton reaction. Evidence for the formation of super-macromolecules. Prog. React. Kinet. Mec., 26(2): 113-137.

[8] Gallard H., Laat J.D., Kinetic modeling of $\mathrm{Fe}(\mathrm{III}) / \mathrm{H} 2 \mathrm{O} 2$ oxidation reactions in dilute aqueous solution using atrazine as a model organic compound, Wat. Res., 34(12): 3107-3116.

[9] Jiang J., Bank J.F., Scholes, C., Subsecond time resolved spin trapping followed by stopped-flow EPR of Fenton reaction products. J. Am. Chem. Soc., 115 (11): 4742-4746.

[10] Kremer M.L., Stein G., The catalytic decomposition of hydrogen peroxide by ferric perchlorate. Trans. Faraday Soc., 55(5):959-973.

[11] The Groundwater Foundation. 2007. Pharmaceuticals and Personal Care Products (PPCPs): An Emerging Issue. 